\title{
Comparison of the effects of human recombinant epidermal growth factor and platelet-rich plasma on healing of rabbit patellar tendon
}

\author{
İnsan rekombinant epidermal büyüme faktörü ve trombositten zengin plazmanın \\ tavşan patellar tendonunun iyileşmesi üzerine etkilerinin karşılaştırılması
}

\author{
Baran Sarıkaya, MD, ${ }^{1}$ Nihat Yumuşak, MD, ${ }^{2}$ Akın Yigin, MD, ${ }^{3}$ Serkan Sipahioğlu, MD, \\ Ünal Yavuz, MD, ${ }^{4}$ Mehmet Akif Altay, MD ${ }^{1}$ \\ 'Department of Orthopedics and Traumatology, Harran University School of Medicine, Sanliurfa, Turkey \\ 2Department of Pathology, Harran University, Faculty of Veterinary Medicine, Sanliurfa, Turkey \\ ${ }^{3}$ Department of Genetics, Harran University, Faculty of Veterinary Medicine, Sanliurfa, Turkey \\ ${ }^{4}$ Department of Surgery, Harran University, Faculty of Veterinary Medicine, Sanliurfa, Turkey
}

\begin{abstract}
Objectives: This study aims to compare the histological healing process and gene expression profile in tendon after the administration of human recombinant epidermal growth factor (hrEGF) and plateletrich plasma (PRP).

Materials and methods: A total of 24 mature New Zealand white rabbits (6-month-old; weight $2.5-3.0 \mathrm{~kg}$ ) were used in the study. Patellar tendons of rabbits were tenotomized and then repaired. Rabbits were separated into three groups and repair areas were injected with $1 \mathrm{~mL}$ hrEGF in group $1(n=9)$ and $1 \mathrm{~mL}$ PRP in group $2(n=9)$. No injection was performed in group 3 (controls, $n=6$ ). Tissue samples were obtained from the repaired patellar tendons of three rabbits each from groups 1 and 2 and of two rabbits from group 3 at the end of the first, second, and fourth weeks, and these tissues were histologically and genetically assessed. Expression levels of tumor necrosis factor-alpha (TNF- $\alpha$ ), interleukin (IL)-6, IL-8, and chemokine receptors (CXCR1, CXCR2) were examined.

Results: The frequency of neovascularization was detected to be higher in group 1 compared to group 3 at the end of the second and fourth weeks ( $p=0.018$ and $p=0.009$, respectively). Group 1 was detected to show more increase in terms of the prevalence of tenocytes $(\mathrm{p}=0.014$ and $p=0.009$, respectively) at the end of the second week, and in terms of collagen intensity at the end of the fourth week $(\mathrm{p}=0.0018$ and $\mathrm{p}=0.034$, respectively) compared to groups 2 and 3. Highest levels of TNF- $\alpha$, IL- 6 , and IL- 8 were detected in group 1, followed by groups 2 and 3 at all time points. Highest CXCR2 gene expression was detected in group 1.

Conclusion: Compared to PRP, hrEGF caused more increase in healing tissue at neovascularization, tenocyte, fibroblast, collagen, and tissue macrophage levels; and higher levels of TNF- $\alpha$, IL-6, IL8, and CXCR2. Intralesional hrEGF administration can effectively accelerate tendon healing.

Keywords: Epidermal growth factor; platelet-rich plasma; tendon injury.
\end{abstract}

öz

Amaç: Bu çalışmada, insan rekombinant epidermal büyüme faktörü (hrEGF) ve trombositten zengin plazma (TZP) uygulamasından sonra tendondaki histolojik iyileşme süreci ve gen ekspresyon profili karşılaştırıldı.

Gereç ve yöntemler: Çalışmada toplam 24 adet erişkin Yeni Zelanda beyaz tavşanı (6 aylık; ağırlık 2,5-3,0 kg) kullanıldı. Tavşanların patellar tendonları tenotomize edildi ve ardından tamir edildi. Tavşanlar üç gruba ayrıldı ve tamir bölgelerine grup 1'de $(\mathrm{n}=9) 1 \mathrm{~mL}$ hrEGF ve grup 2'de $(\mathrm{n}=9) 1 \mathrm{~mL}$ TZP enjeksiyonu yapıldı. Grup 3'te (kontroller, $n=6$ ) enjeksiyon yapılmadı. Birinci, ikinci ve dördüncü hafta sonunda grup 1 ve 2 'den üçer, grup 3 'ten ise iki tavşanın tamir edilen patellar tendonlarından doku örnekleri alındı ve bu dokular histolojik ve genetik olarak incelendi. Tümör nekroz faktör alfa (TNF- $\alpha$ ), interlökin (IL)-6 ve IL- 8 ile kemokin reseptörlerinin (CCXCR1, CCXCR2) ekspresyon düzeyleri irdelendi.

Bulgular: İki ile dördüncü hafta sonunda neovaskülarizasyon frekansının grup 3'e kıyasla grup 1'de daha yüksek olduğu tespit edildi (sırasiyla $\mathrm{p}=0,018$ ve $\mathrm{p}=0,009)$. Grup 1'in ikinci hafta sonunda tenosit prevalansı bakımından (sırasıyla $\mathrm{p}=0,014$ ve $\mathrm{p}=0,009$ ), dördüncü hafta sonunda ise kollajen yoğunluğu bakımından (sırasıyla $\mathrm{p}=0,0018$, $\mathrm{p}=0,034)$ grup 2 ve 3'e kıyasla daha fazla artış gösterdiği tespit edildi. Bir, iki ve dördüncü hafta sonunda en yüksek TNF- $\alpha$, IL-6 ve IL-8 düzeyleri grup 1'de saptandı, bunları tüm zaman noktalarında grup 2 ve 3 takip etti. En yüksek CXCR2 gen ekspresyonu grup 1'de saptandı.

Sonuç: Trombositten zengin plazma ile karşılaştırıldığında, hrEGF iyileşme dokusunda neovaskülarizasyon, tenosit, fibroblast, kollajen ve doku makrofaj düzeylerinde daha fazla artışa ve daha yüksek TNF- $\alpha$, IL-6, IL8 ve CXCR2 düzeylerine neden oldu. İntralezyonel hrEGF uygulaması, tendon iyileşmesini etkili bir şekilde hızlandırabilir. Anahtar sözcükler: Epidermal büyüme faktörü; trombositten zengin plazma; tendon yaralanmasi.

- Received: February 28, 2017 Accepted: May 09, 2017

- Correspondence: Baran Sarıkaya, MD. Harran Üniversitesi Tıp Fakültesi Ortopedi ve Travmatoloji Anabilim Dalı, 63100 Şanlıurfa, Turkey. Tel: +90 414 - 3183031 e-mail: baransarikaya@yahoo.com 
The process of tendon healing takes more time because of lower blood supply and slower metabolic rate compared to other soft tissues. ${ }^{[1]}$ The effects of several growth factors on tendon healing have been reported in various studies. ${ }^{[1,2]}$ In vivo and in vitro studies have shown that epidermal growth factor (EGF) expression is enhanced in the inflammatory region after tendon injury, while having an additive effect on tenoblast migration. ${ }^{[3,4]}$ Other studies have evaluated the effects of platelet-rich plasma (PRP) on the healing of tendon injuries and tendinopathy, and have reported a positive association between PRP and the healing process. ${ }^{[5,6]}$

Human epidermal growth factor is involved in cell growth, proliferation, and differentiation. Epidermal growth factor was isolated from the submaxillary salivary glands of mice in the 1960s. ${ }^{[7]}$ Epidermal growth factors are synthesized by fibroblasts, monocytes, macrophages, and platelets and affect epidermal cells, smooth muscles, and fibroblasts. ${ }^{[7,8]}$ Intralesional use of human recombinant EGF (hrEGF) in diabetic wound treatment has been reported. ${ }^{[9,10]}$

Platelet-rich plasma, derived from the patient's own blood, contains high concentrations of platelets. ${ }^{[11]}$ There are numerous growth factors in platelet $\alpha$ granules, including platelet-derived growth factor, transforming growth factor- $\beta$, EGF, vascular endothelial growth factor, platelet-derived angiogenesis factor, plateletderived epidermal growth factor, platelet factor-4, and insulin-like growth factor. ${ }^{[12]}$ Growth factors are released when platelets are activated, and tissue healing and regeneration are initiated as a result of cellular chemotaxis, proliferation, differentiation, and angiogenesis. ${ }^{[12]}$ PRP is commonly used in clinical practice for the treatment of bone, tendon, cartilage, and connective tissue injuries and osteoarthritis. ${ }^{[13,14]}$

To the best of our knowledge, no experimental study on the benefits of hrEGF in tendon healing has been reported. ${ }^{[15]}$ We anticipated that hrEGF would induce a greater effect on tendon healing compared to PRP. Therefore, in this study, we aimed to compare the histological healing process and gene expression profile in tendon after the administration of hrEGF and PRP.

\section{MATERIALS AND METHODS}

A total of 24 mature New Zealand white rabbits (6-month-old; weight $2.5-3.0 \mathrm{~kg}$ ) were used in the study, which was conducted between August 2016 and November 2016 at the Experimental Research Laboratory of Veterinary Faculty of Harran University. The study was approved by the Dollvet Animal Care and Use Committee and was performed according to the guidelines of the Association for the Assessment and Accreditation of Laboratory Animal Care. Rabbits were randomly divided into three groups: the hrEGF group (group 1, n=9), PRP group (group 2, n=9), and control group (group 3, $\mathrm{n}=6$ ). Patellar tendons were tenotomized and repaired. Following repair, they were injected with $1 \mathrm{~mL}$ hrEGF (Heberprot-P, $75 \mu \mathrm{g}$; group 1) or $1 \mathrm{~mL}$ PRP (group 2). Group 3 received no injection.

As described by Anaguchi et al., ${ }^{[16]}$ a longitudinal skin incision was performed on the skin overlying the middle of the patellar tendon. The superficial surrounding fascia was cut longitudinally to expose the tendon. Then, the deep fascia overlying the tendon was opened and a full-thickness sample ( $2 \mathrm{~mm}$ wide, $10 \mathrm{~mm}$ long) was excised from the central portion of the tendon. Next, the tendon was repaired using 3/0 polypropylene (Prolene; Ethicon, Somerville, NJ), and the fascia and skin were covered. After the first, second, and fourth weeks, a tissue sample $(2 \mathrm{~mm}$ wide, $10 \mathrm{~mm}$ long) containing the repair site was excised from the central portion.

For the preparation of PRP and platelet counting, blood samples (10 and $1 \mathrm{~mL}$, respectively) were obtained from the central ear veins of the rabbits, stored in tubes containing sodium citrate, and centrifuged (150 g, 20 minutes). Next, after removing the supernatant, the sample was recentrifuged (450 g, 10 minutes). As a result, the lower part was plateletrich and the upper part was platelet-poor. The lower portion was aspirated and stored in tubes. ${ }^{[13]}$ Thus, $2 \mathrm{~mL}$ PRP was prepared from each $10 \mathrm{~mL}$ sample of blood. Then, $1 \mathrm{~mL}$ samples of plasma were sent to a laboratory for platelet counting. The results were compared against the values of normal peripheral blood. The platelet counts were 2.5-4.5 times higher in PRP than in normal peripheral blood (mean $=3.1 \pm 1$ ). Prior to the injection, autogenous PRPs were mixed with $10 \%$ calcium chloride and $100 \mathrm{U} / \mathrm{mL}$ thrombin at a ratio of $1 / 0.15$. After a wait time of 1 minute for platelet activation, a viscous and injectable material was obtained.

Biopsy samples were fixed in 10\% buffered formaldehyde for histopathological assessment and then mounted in paraffin wax blocks. Sections $(5 \mu \mathrm{m}$ thick) were cut from the paraffin wax blocks with a microtome and subsequently deparaffinized in xylol and rehydrated through a descending alcohol series. After hematoxylin and eosin staining, the samples were evaluated under a light microscope (Olympus BX53, DP73 camera; Olympus, Tokyo, Japan). Histopathological healing was assessed in terms of inflammation, tenocytes, tissue macrophages, 
TABLE I

Grading of tendon healing in histological samples

\begin{tabular}{|c|c|c|c|c|c|c|c|c|}
\hline & Rabbit & Inflammation & $\begin{array}{c}\text { Tissue } \\
\text { macrophage }\end{array}$ & Neovascularization & Tenocyte & Fibroblast & Collagen & Week \\
\hline \multirow[t]{9}{*}{ hrEGF } & 1 & 3 & 1 & 0 & 0 & 1 & 0 & \multirow{3}{*}{$1^{\text {st }}$} \\
\hline & 2 & 3 & 2 & 0 & 0 & 1 & 0 & \\
\hline & 3 & 3 & 2 & 1 & 0 & 2 & 0 & \\
\hline & 4 & 2 & 3 & 3 & 2 & 3 & 3 & \multirow{3}{*}{$2^{\text {nd }}$} \\
\hline & 5 & 3 & 2 & 3 & 2 & 2 & 3 & \\
\hline & 6 & 2 & 2 & 3 & 2 & 3 & 2 & \\
\hline & 7 & 1 & 2 & 3 & 3 & 3 & 3 & \multirow{3}{*}{$4^{\text {th }}$} \\
\hline & 8 & 0 & 2 & 3 & 3 & 3 & 3 & \\
\hline & 9 & 1 & 2 & 3 & 3 & 3 & 3 & \\
\hline \multirow[t]{9}{*}{ PRP } & 10 & 3 & 2 & 0 & 0 & 1 & 0 & \multirow{3}{*}{$1^{\text {st }}$} \\
\hline & 11 & 3 & 1 & 0 & 0 & 1 & 0 & \\
\hline & 12 & 3 & 0 & 0 & 0 & 0 & 0 & \\
\hline & 13 & 1 & 1 & 1 & 0 & 1 & 2 & \multirow{3}{*}{$2^{\text {nd }}$} \\
\hline & 14 & 1 & 1 & 2 & 0 & 1 & 2 & \\
\hline & 15 & 2 & 2 & 2 & 1 & 2 & 2 & \\
\hline & 16 & 0 & 1 & 2 & 2 & 2 & 2 & \\
\hline & 17 & 1 & 1 & 2 & 2 & 2 & 2 & $4^{\text {th }}$ \\
\hline & 18 & 1 & 1 & 2 & 2 & 3 & 2 & \\
\hline \multirow[t]{6}{*}{ Control } & 19 & 3 & 1 & 0 & 0 & 0 & 1 & \multirow{2}{*}{$1^{\text {st }}$} \\
\hline & 20 & 3 & 1 & 0 & 0 & 0 & 0 & \\
\hline & 21 & 3 & 1 & 1 & 1 & 2 & 2 & \multirow{2}{*}{$2^{\text {nd }}$} \\
\hline & 22 & 2 & 1 & 1 & 1 & 2 & 2 & \\
\hline & 23 & 2 & 2 & 1 & 1 & 2 & 2 & \multirow{2}{*}{$4^{\text {th }}$} \\
\hline & 24 & 2 & 2 & 1 & 1 & 2 & 2 & \\
\hline
\end{tabular}

0: Absent; 1: Mild; 2: Moderate; 3: Severe; hrEGF: Human recombinant epidermal growth factor; PRP: Platelet-rich plasma.

fibroblasts, neovascularization, and the quantity of collagen. The results were scored based on the method of Najafbeygi et al: ${ }^{[17]} 0$, absent; 1 , mild; 2, moderate; and 3, severe (Table I).

Tissue samples were frozen in messenger ribonucleic acid (RNA) solution at $-80^{\circ} \mathrm{C}$. Then, 30-35 $\mathrm{mg}$ from each sample was homogenized at 6,500 rpm for 40 seconds using a High Pure RNA Tissue Kit Tissue Lysis/Binding Buffer (Roche). Tissue samples were kept on an ice block at $4{ }^{\circ} \mathrm{C}$ for 2 minutes, rehomogenized at 6,500 rpm for 40 seconds, and again kept on an ice block at $4{ }^{\circ} \mathrm{C}$ for 5-10 minutes. Absolute ethanol $(175 \mu \mathrm{L})$ was added and RNA isolation was performed using the kit protocol. The purity and integrity of RNA was assessed using Nanodrop and gel electrophoresis devices. Complementary deoxyribonucleic acid (cDNA) was synthesized in two stages using a Transcriptor First Strand cDNA Synthesis Kit (Roche).

The mixture for PCR consisted of real-time PCR (master mix), 12.4 $\mu \mathrm{L}$ double-distilled water, $1.6 \mu \mathrm{L}$ magnesium ion $(25 \mathrm{mM}), 2.0 \mu \mathrm{L}$ Light Cycler DNA Master SYBR Green I (Roche), 10× concentration, $1.0 \mu \mathrm{L}$ primer forward (target or beta actin [ACTB]), and $1.0 \mu \mathrm{L}$ primer reverse (target or ACTB) (total volume $=18 \mu \mathrm{L}$ ). Then, $2.0 \mu \mathrm{L}$ target cDNA or ACTB was added to each sample to obtain a final volume of $20 \mu \mathrm{L}$.

Real-time polymerase chain reaction (PCR) consisted of one cycle of $95^{\circ} \mathrm{C}$ for 30 seconds, 45 cycles of $95^{\circ} \mathrm{C}$ for 0 seconds, $60^{\circ} \mathrm{C}$ for 30 seconds, and $72{ }^{\circ} \mathrm{C}$ for 20 seconds, and one cycle of cooling at $40{ }^{\circ} \mathrm{C}$ for 30 seconds. After adding cDNA $(5 \mu \mathrm{L})$, each sample was loaded on to one plate in a Light Cycler 480 (Roche). Amplification curves and the crossing point (Cp) were checked for each sample. The concentrations of samples were obtained based on the crossing point and 2- ${ }^{\triangle \triangle C T}$ data. During real-time PCR, the expression levels of a reference gene (housekeeping gene) and a target gene were measured for each tissue sample. For quantitative analysis of gene expression, standards were selected among rabbit samples. Thus, an amplified sample was accepted as the standard 
in real-time PCR. Standard samples were diluted at ratios of $1 / 10,1 / 100$, and $1 / 1,000$. The expression levels of the housekeeping gene ( $\beta$-actin) and target genes, namely tumor necrosis factor-alpha (TNF- $\alpha$ ), interleukin (IL)-6, IL-8, and chemokine receptors (CXCR1, CXCR2) were evaluated for all groups. For the evaluation of real-time PCR data, Light Cycler 480 software (ver. 1.5) was used.

Results were computed using the concentration detection method and $2^{\Delta \Delta \mathrm{CT}} \mathrm{Cp}$ values. Then, the mean value of the expression levels of the target genes was proportioned to the mean value of the expression level of $\beta$-actin.

\section{Statistical analysis}

Histopathological data were analyzed using KruskalWallis tests, and pairwise multiple comparison tests were used to compare scores between different times and groups. Data are expressed as medians (minimummaximum). We used a one-way analysis of variance test to assess significant differences in gene expression levels among all samples. Statistical analyses were performed using the IBM SPSS for Windows version 23.0 software (IBM Corp., Armonk, USA), and a $p$ value of $<0.05$ was considered statistically significant.

\section{RESULTS}

The prevalence of tissue macrophages was higher in group 1 at the first, second, and fourth weeks and significantly higher than group 2 at the end of the fourth week $(p=0.018)$. Neovascularization showed an increasing tendency in all groups at the end of the fourth week. Group 1 showed significantly greater

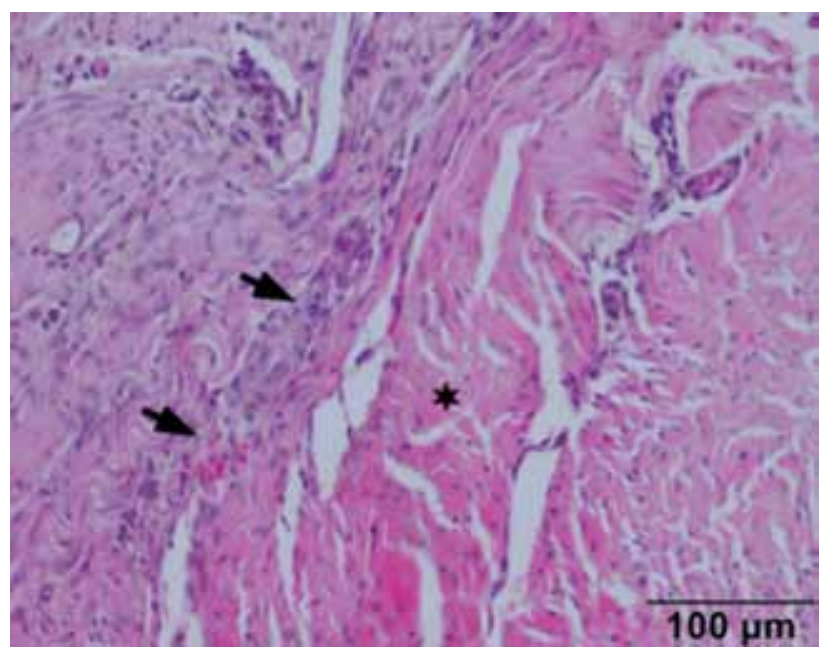

Figure 1. Histologically complete healing of patellar tendon in a rabbit with human recombinant epidermal growth factor applied at end of fourth week (black arrows: dense fibroblasts, star: complete healing) $(\mathrm{H}-\mathrm{E} \times 200)$. neovascularization compared to group 3 at the end of the second and fourth weeks ( $p=0.018$ and $p=0.009$, respectively). Group 1 showed significantly more tenocytes than groups 2 and 3 at the end of the second week $(p=0.014)$. An increase in tenocytes was detected in all groups at the end of the fourth week. Group 1 had significantly more tenocytes than group 3 at the end of the fourth week. Group 1 had more fibroblasts than the other groups at all time points, and showed greater collagen formation than groups $2(\mathrm{p}=0.018)$ and $3(p=0.034)$ at the end of the fourth week. In intragroup comparisons, both groups 1 and 2 showed significantly greater collagen formation at the end of the fourth week versus the first week $(\mathrm{p}<0.05$; Figures 1, 2).

The expression levels of TNF- $\alpha$, IL- 6 , and IL-8 were significantly higher in group 1 than in groups 2 and 3 at the end of the first, second, and fourth weeks $(\mathrm{p}<0.05$; Table II). These were higher in group 2 than in group 3; however, the difference was not statistically significant $(\mathrm{p}>0.05)$. The expression of CXCR2 was highest in group 1 at the end of the fourth week. This difference was statistically significant compared to group 2 ( $\mathrm{p}<0.05$; Table II).

\section{DISCUSSION}

This study confirms the positive effects of hrEGF on histological changes and gene expression levels in tendon healing. To the best of our knowledge, no experimental study on the benefits of hrEGF in tendon healing has been reported. However, there are many studies on the benefits of PRP in tendon healing. ${ }^{[13,14]}$ Thus, the present study investigated the

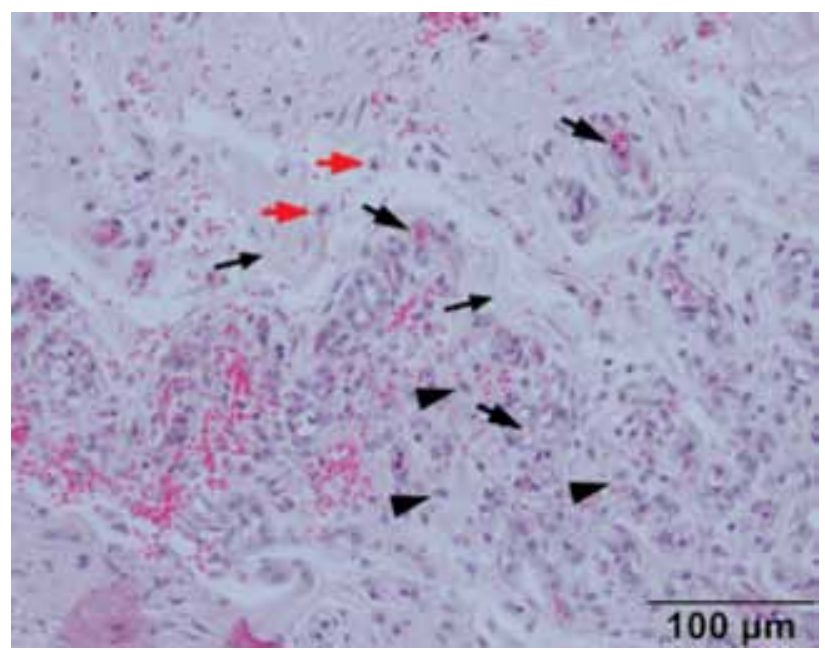

Figure 2. Histological healing of patellar tendon in a rabbit with platelet-rich plasma applied at end of fourth week (thick arrows: neovascularization, thin arrows: collagen, head of arrows: tissue macrophages, red arrows: tenocytes) $(\mathrm{H}-\mathrm{E} \times 200)$. 
TABLE II

Evaluation of gene analysis

\begin{tabular}{|c|c|c|c|c|c|c|c|}
\hline \multirow[b]{2}{*}{ Variables } & \multicolumn{2}{|c|}{$1^{\text {st }}$} & \multicolumn{2}{|c|}{$2^{\text {nd }}$} & \multicolumn{2}{|c|}{$4^{\text {th }}$} & \multirow{2}{*}{$\begin{array}{c}P_{\text {within }} \\
\text { groups }\end{array}$} \\
\hline & Median & Min-Max & Median & Min-Max & Median & Min-Max & \\
\hline \multicolumn{8}{|l|}{ TNF- $\alpha$} \\
\hline Control (n=2) & 10.6 & $10.5-10.8$ & 10.7 & $10.6-10.8$ & 10.8 & $10.8-10.9$ & 0.485 \\
\hline hrEGF $(n=3)$ & 26.3 & $24.6-28.4$ & 28.6 & $27.8-30.2$ & 29.3 & 28.2-31.9 & 0.189 \\
\hline $\operatorname{PRP}(n=3)$ & 13.5 & $12.1-15.8$ & 14.1 & $13.8-15.0$ & 18.9 & $17.8-19.6$ & $0.005^{\star}$ \\
\hline$P$ Between groups & \multicolumn{2}{|c|}{0.001} & \multicolumn{2}{|c|}{0.001} & \multicolumn{2}{|c|}{0.001} & \\
\hline \multicolumn{8}{|l|}{ IL6 } \\
\hline Control (n=2) & 10.7 & $10.4-11.1$ & 10.8 & $10.8-10.8$ & 10.8 & $10.7-10.9$ & 0.981 \\
\hline hrEGF $(n=3)$ & 19.2 & $17.8-20.3$ & 19.2 & $17.2-23.9$ & 19.8 & $19.5-19.8$ & 0.848 \\
\hline $\operatorname{PRP}(n=3)$ & 10.2 & $10.1-15.3$ & 12.4 & $9.8-14.1$ & 11.3 & $9.1-15.8$ & 0.994 \\
\hline$P$ Between groups & \multicolumn{2}{|c|}{0.01} & \multicolumn{2}{|c|}{$0.016^{*}$} & \multicolumn{2}{|c|}{$0.01^{*}$} & \\
\hline \multicolumn{8}{|l|}{ IL8 } \\
\hline Control (n=2) & 15.1 & $14.7-15.6$ & 15.5 & $15.5-15.5$ & 15.2 & $14.9-15.6$ & 0.761 \\
\hline hrEGF $(n=3)$ & 34.0 & 28.4-35.3 & 34.1 & $31.4-39.1$ & 34.9 & $30.6-41.4$ & 0.691 \\
\hline PRP $(n=3)$ & 18.7 & $18.2-20.7$ & 19.6 & $18.9-20.3$ & 20.5 & $18.4-21.7$ & 0.656 \\
\hline$P$ Between groups & \multicolumn{2}{|c|}{$0.01^{*}$} & \multicolumn{2}{|c|}{$0.001^{*}$} & \multicolumn{2}{|c|}{$0.003^{*}$} & \\
\hline \multicolumn{8}{|l|}{ CCXCR1 } \\
\hline Control $(n=2)$ & 13.6 & $13.5-13.8$ & 13.8 & $13.5-14.2$ & 15.1 & $14.7-15.6$ & 0.095 \\
\hline $\operatorname{hrEGF}(n=3)$ & 12.6 & $11.8-13.3$ & 12.8 & $12.1-13.7$ & 13.1 & $11.6-20.4$ & 0.534 \\
\hline $\operatorname{PRP}(n=3)$ & 15.4 & $9.8-17.40$ & 13.2 & $12.7-17.3$ & 14.5 & $13.4-19.1$ & 0.837 \\
\hline$P$ Between groups & \multicolumn{2}{|c|}{0.741} & \multicolumn{2}{|c|}{0.57} & \multicolumn{2}{|c|}{0.974} & \\
\hline \multicolumn{8}{|l|}{ CCXCR2 } \\
\hline Control $(n=2)$ & 12.2 & $12.1-12.4$ & 12.7 & $12-13.5$ & 12.5 & $11.9-13.1$ & 0.830 \\
\hline hrEGF $(n=3)$ & 19.8 & $14.4-20.6$ & 18.7 & $17.8-22.5$ & 18.1 & $17.6-26.3$ & 0.741 \\
\hline $\operatorname{PRP}(n=3)$ & 10.5 & $9.1-15.1$ & 11.5 & 10.1-13.2 & 11.7 & $9.4-12.2$ & 0.952 \\
\hline$P$ Between groups & \multicolumn{2}{|c|}{0.074} & \multicolumn{2}{|c|}{$0.008^{*}$} & \multicolumn{2}{|c|}{$0.033^{*}$} & \\
\hline
\end{tabular}

Min: Minimum; Max: Maximum; * Significant at 0.05 level; TNF- $\alpha$ : Tumor necrosis factor-alpha; hrEGF: Human recombinant epidermal growth factor; PRP: Platelet-rich plasma; IL: Interleukin; CXCR1, CXCR2: Chemokine receptors.

effects of hrEGF on tendon healing and compared its effects with those of PRP. Despite empirical studies on the effects of growth factors, including insulin-like growth factor, transforming growth factor- $\beta 1$, vascular endothelial growth factor, bone morphogenetic protein, and fibroblast growth factor on tendon healing, the relationship between tendon healing and growth factors and cytokines has not been fully characterized. ${ }^{[18,19]}$

Tendon healing begins with an inflammatory process and continues with cell proliferation and remodelling. Following the migration of inflammatory cells to the injured site, angiogenesis is triggered as a result of phagocytosis by macrophages and monocytes. The migration of tenocytes occurs progressively, and remodelling proceeds with collagen production. ${ }^{[18,20]}$ In the present study, the healing of rabbit patellar tendons was examined histopathologically in three study groups, and the inflammatory response was high, as expected, in all groups at the end of the first week. Inflammation was largely reduced in all groups at the end of the fourth week. In an experimental study, the degree of inflammation was lower in the PRP group than in the control group. ${ }^{[21]}$ Similarly, this study found that inflammation was lower in the PRP and hrEGF groups than in the control group after four weeks. Thus, it may be concluded that the inflammatory process is faster in the hrEGF and PRP groups than in the control group.

Tissue macrophage levels were highest in the hrEGF group. The quantity of tissue macrophages was comparable between the PRP and control groups. One study, reporting a correlation between tissue macrophages and expression of hrEGF, demonstrated that activation of EGF receptors plays an important role in cell migration in acute wounds and that tissue 
macrophages are the cellular source of EGF ligands. ${ }^{[2]}$ Thus, exogenously administered hrEGF may have caused an increase in tissue macrophages in our study.

Neovascularization was significantly higher in the hrEGF group at the end of the first week. It increased progressively in all groups until the end of the fourth week. The relatively poor vascularization of tendons is considered one of the reasons for its limited healing potential. Thus, a therapeutic agent applied for tendon repair should target neovascularization. It has been demonstrated that PRP induces significant neovascularization. ${ }^{[23]}$ Vascular endothelial growth factor, a powerful stimulator of angiogenesis, is abundant in PRP and is thought to enhance neovascularization. ${ }^{[23]}$ It has been shown that hrEGF also enhances neovascularization. ${ }^{[2]}$ In our study, neovascularization was higher in the PRP group than in the control group. However, it was highest in the hrEGF group. It has been shown that hrEGF induces mitosis and chemotaxis in endothelial cells. ${ }^{[25]}$ These effects of hrEGF may also positively influence neovascularization.

In our study, collagen production and tenocyte levels were significantly higher in the hrEGF group, in line with some previous studies. In one experimental study, collagen and DNA content were significantly higher in an EGF group than in placebo controls. ${ }^{[26]}$ In another study, PRP delivery to injured tendons increased precocious deposition of fibrillar collagen in the healing tendons. ${ }^{[27]}$ PRP promotes proliferation, metabolic activity, and differentiation of mesenchymal cells into active tenocytes. ${ }^{[28]}$ EGF has proliferative effects on cells of both mesodermal and ectodermal origin, particularly keratinocytes and fibroblasts. ${ }^{[3,4]}$ In our study, the hrEGF group had more fibroblasts than the other groups at all time points.

The use of cy tokines and growth factors to enhance tendon healing remains largely experimental and has been restricted to in vitro studies and animal models. Because cytokines and growth factors regulate tendon differentiation in embryogenesis, they can effectively mediate tendon healing. ${ }^{[19]}$ However, the effects of cytokines on wound healing are still unclear. TNF- $\alpha$ affects tenocytes and induces collagen and cytokine synthesis at the wound site; IL-8 induces angiogenesis and IL-6 enhances collagen synthesis. ${ }^{[29]}$ Chemokines show their effects via receptors such as $\mathrm{G}$ proteins, CXCR1, and CXCR2, which have key roles in chemotaxis and cellular activation. ${ }^{[30]}$ Proinflammatory cytokines, particularly IL-1, IL- 6 , and TNF- $\alpha$, are upregulated during the inflammatory phase of wound healing. ${ }^{[31]}$
In support of a role for proinflammatory cytokines in wound repair, a previous study found that the levels of IL-1, IL-6, and TNF- $\alpha$ were strongly upregulated during the inflammatory phase of healing, and polymorphonuclear leukocytes and macrophages were the major source of these cytokines. ${ }^{[32]}$ Some studies have shown that PRP and EGF promote the healing process by increasing cytokine levels. Platelet-rich plasma produces a considerable amount of IL-6, IL-1, IL-8, and TNF- $\alpha \cdot{ }^{[33]}$ In an experimental study, EGF increased biological activity and mRNA levels for IL-1 and IL-6. ${ }^{[34]}$ A study that investigated the effects of chemokines demonstrated that CXCR2 is the primary functional chemokine receptor in mediating endothelial cell chemotaxis. ${ }^{[35]}$ Our findings are consistent with these studies. We found higher expression of cytokines in the PRP and hrEGF groups than in the control group. Targeted gene expression was highest in the hrEGF group. Similarly, levels of tissue macrophages, a major source of cytokines, were highest in the hrEGF group. The efficiency of macrophage migration in the hrEGF group and the detection of higher cytokine levels in this group are mutually supportive findings.

The presence of chemokine receptors in inflammatory cells suggests that chemokines also contribute to the regulation of re-epithelialization, tissue remodelling, and angiogenesis. In an experimental study, CXCR2 deficiency resulted in defective neutrophil recruitment, delayed monocyte recruitment, and decreased secretion of the proinflammatory cytokine IL- 1 in the wound area. ${ }^{[36]}$ Our study demonstrated that the expression of CXCR1, which has high specificity for IL-8, and CXCR2, which has specificity for IL-8 and other cytokines, was higher in all groups compared to the reference gene. In addition, the expression of CXCR2 was highest in the hrEGF group, as with cytokines. It has been evidenced that the increase in CXCR2 expression is closely related to the healing cycle. In our study, the expression of both CXCR2 and cytokines was higher in the hrEGF group.

Our study has some limitations including the lack of biomechanical analyses and small sample size. This investigation included a relatively insufficient number of animal. Although histological and genetic evaluations are important for tendon healing process, biomechanical test results are also important for the evaluation of tendon repairs.

In conclusion, we found a higher expression of cytokines in the hrEGF group, with positive effects on tissue healing. Similarly, considering the histological and genetic criteria of our study, hrEGF is superior 
over PRP. There are many studies on the effects of PRP on tendon healing and its use in tendon pathologies. However, to the best of our knowledge, the efficacy of the clinical use of hrEGF for tendon healing has not been reported to date. We believe that hrEGF can be considered a viable option for tendon healing. However, more studies are needed to investigate the effects of hrEGF on tendon healing.

\section{Declaration of conflicting interests}

The authors declared no conflicts of interest with respect to the authorship and/or publication of this article.

\section{Funding}

The authors received no financial support for the research and/or authorship of this article.

\section{REFERENCES}

1. Fernández-Sarmiento JA, Domínguez JM, Granados MM, Morgaz J, Navarrete R, Carrillo JM, et al. Histological study of the influence of plasma rich in growth factors (PRGF) on the healing of divided Achilles tendons in sheep. J Bone Joint Surg [Am] 2013;95:246-55.

2. Molloy T, Wang Y, Murrell G. The roles of growth factors in tendon and ligament healing. Sports Med 2003;33:381-94.

3. Tsubone T, Moran SL, Amadio PC, Zhao C, An KN. Expression of growth factors in canine flexor tendon after laceration in vivo. Ann Plast Surg 2004;53:393-7.

4. Jann HW, Stein LE, Slater DA. In vitro effects of epidermal growth factor or insulin-like growth factor on tenoblast migration on absorbable suture material. Vet Surg 1999;28:268-78.

5. Peerbooms JC, Sluimer J, Bruijn DJ, Gosens T. Positive effect of an autologous platelet concentrate in lateral epicondylitis in a double-blind randomized controlled trial: platelet-rich plasma versus corticosteroid injection with a 1-year followup. Am J Sports Med 2010;38:255-62.

6. Sánchez M, Anitua E, Azofra J, Andía I, Padilla S, Mujika I. Comparison of surgically repaired Achilles tendon tears using platelet-rich fibrin matrices. Am J Sports Med 2007;35:245-51.

7. Cohen S. Isolation of a mouse submaxillary gland protein accelerating incisor eruption and eyelid opening in the new-born animal. J Biol Chem 1962;237:1555-62.

8. Nanney LB. Epidermal and dermal effects of epidermal growth factor during wound repair. J Invest Dermatol 1990;94:624-9.

9. Dumantepe M, Fazliogullari O, Seren M, Uyar I, Basar F. Efficacy of intralesional recombinant human epidermal growth factor in chronic diabetic foot ulcers. Growth Factors 2015;33:128-32.

10. Fernández-Montequín JI, Betancourt BY, Leyva-Gonzalez G, Mola EL, Galán-Naranjo K, Ramírez-Navas M, et al. Intralesional administration of epidermal growth factorbased formulation (Heberprot-P) in chronic diabetic foot ulcer: treatment up to complete wound closure. Int Wound J 2009;6:67-72.

11. Sundman EA, Cole BJ, Fortier LA. Growth factor and catabolic cytokine concentrations are influenced by the cellular composition of platelet-rich plasma. Am J Sports Med 2011;39:2135-40.
12. Alsousou J, Thompson M, Hulley P, Noble A, Willett K. The biology of platelet-rich plasma and its application in trauma and orthopaedic surgery: a review of the literature. J Bone Joint Surg [Br] 2009;91:987-96.

13. Kanthan SR, Kavitha G, Addi S, Choon DS, Kamarul T. Platelet-rich plasma (PRP) enhances bone healing in nonunited critical-sized defects: a preliminary study involving rabbit models. Injury 2011;42:782-9.

14. Fitzpatrick J, Bulsara M, Zheng MH. The Effectiveness of Platelet-Rich Plasma in the Treatment of Tendinopathy: A Meta-analysis of Randomized Controlled Clinical Trials. Am J Sports Med 2017;45:226-233.

15. Atik OŞ. Are all case reports worth publishing? Eklem Hastalik Cerrahisi 2016;27:61.

16. Anaguchi Y, Yasuda K, Majima T, Tohyama H, Minami A, Hayashi K. The effect of transforming growth factor-beta on mechanical properties of the fibrous tissue regenerated in the patellar tendon after resecting the central portion. Clin Biomech (Bristol, Avon) 2005;20:959-65.

17. Najafbeygi A, Fatemi MJ, Lebaschi AH, Mousavi SJ, Husseini SA, Niazi M. Effect of Basic Fibroblast Growth Factor on Achilles Tendon Healing in Rabbit. World J Plast Surg 2017;6:26-32.

18. Sharma P, Maffulli N. Tendon injury and tendinopathy: healing and repair. J Bone Joint Surg [Am] 2005;87:187-202.

19. Müller SA, Todorov A, Heisterbach PE, Martin I, Majewski M. Tendon healing: an overview of physiology, biology, and pathology of tendon healing and systematic review of state of the art in tendon bioengineering. Knee Surg Sports Traumatol Arthrosc 2015;23:2097-105.

20. Aydın BK, Altan E, Acar MA, Erkoçak ÖF, Ugraş S. Effect of Ankaferd blood stopper ${ }^{\circledR}$ on tendon healing: an experimental study in a rat model of Achilles tendon injury. Eklem Hastalik Cerrahisi 2015;26:31-7.

21. Hapa O, Cakıcı H, Kükner A, Aygün H, Sarkalan N, Baysal G. Effect of platelet-rich plasma on tendon-to-bone healing after rotator cuff repair in rats: an in vivo experimental study. Acta Orthop Traumatol Turc 2012;46:301-7.

22. Rappolee DA, Mark D, Banda MJ, Werb Z. Wound macrophages express TGF-alpha and other growth factors in vivo: analysis by mRNA phenotyping. Science 1988;241:708-12.

23. Bosch G, Moleman M, Barneveld A, van Weeren PR, van Schie HT. The effect of platelet-rich plasma on the neovascularization of surgically created equine superficial digital flexor tendon lesions. Scand J Med Sci Sports 2011;21:554-61.

24. Fernández-Montequín JI, Infante-Cristiá E, ValenzuelaSilva C, Franco-Pérez N, Savigne-Gutierrez W, ArtazaSanz $\mathrm{H}$, et al. Intralesional injections of Citoprot-P (recombinant human epidermal growth factor) in advanced diabetic foot ulcers with risk of amputation. Int Wound J 2007;4:333-43.

25. Schultz GS, Grant MB. Neovascular growth factors. Eye (Lond) 1991;5:170-80.

26. Buckley A, Davidson JM, Kamerath CD, Woodward SC. Epidermal growth factor increases granulation tissue formation dose dependently. J Surg Res 1987;43:322-8.

27. Kaux JF, Drion PV, Colige A, Pascon F, Libertiaux V, Hoffmann A, et al. Effects of platelet-rich plasma (PRP) on the healing of Achilles tendons of rats. Wound Repair Regen 2012;20:748-56. 
28. Zhang J, Wang JH. Platelet-rich plasma releasate promotes differentiation of tendon stem cells into active tenocytes. Am J Sports Med 2010;38:2477-86.

29. Ackermann PW, Domeij-Arverud E, Leclerc P, Amoudrouz P, Nader GA. Anti-inflammatory cytokine profile in early human tendon repair. Knee Surg Sports Traumatol Arthrosc 2013;21:1801-6.

30. Theilgaard-Mönch K, Knudsen S, Follin P, Borregaard $\mathrm{N}$. The transcriptional activation program of human neutrophils in skin lesions supports their important role in wound healing. J Immunol 2004;172:7684-93.

31. Singer AJ, Clark RA. Cutaneous wound healing. N Engl J Med 1999;341:738-46.

32. Grellner W, Georg T, Wilske J. Quantitative analysis of proinflammatory cytokines (IL-1beta, IL-6, TNF-alpha) in human skin wounds. Forensic Sci Int 2000;113:251-64.

33. Pochini AC, Antonioli E, Bucci DZ, Sardinha LR,
Andreoli CV, Ferretti M, et al. Analysis of cytokine profile and growth factors in platelet-rich plasma obtained by open systems and commercial columns. Einstein (Sao Paulo) 2016;14:391-7.

34. Le PT, Lazorick S, Whichard LP, Haynes BF, Singer KH. Regulation of cytokine production in the human thymus: epidermal growth factor and transforming growth factor alpha regulate mRNA levels of interleukin 1 alpha (IL-1 alpha), IL-1 beta, and IL-6 in human thymic epithelial cells at a post-transcriptional level. J Exp Med 1991;174:1147-57.

35. Addison CL, Daniel TO, Burdick MD, Liu H, Ehlert JE, Xue YY, et al. The CXC chemokine receptor 2, CXCR2, is the putative receptor for ELR+ CXC chemokine-induced angiogenic activity. J Immunol 2000;165:5269-77.

36. Devalaraja RM, Nanney LB, Du J, Qian Q, Yu Y, Devalaraja $\mathrm{MN}$, et al. Delayed wound healing in CXCR2 knockout mice. J Invest Dermatol 2000;115:234-44. 